\title{
Research on the Construction of the Mode of Financial Shared Service Center in the Internet Plus Era*
}

\author{
Jianghong Yao \\ Business School \\ Xi'an FanYi University \\ Xi'an, China
}

\begin{abstract}
With the advent of the Internet plus era and the advancement of trend of economic globalization, the management mode of enterprises has changed from simplification to intensification. As an innovative organization, the mode of financial shared service centers effectively satisfies and upgrades the requirement of financial management because of business development of multinational corporations. This article takes the theory and concept of financial shared service as the entry point, analyzes the necessity of the implementation of financial shared service and the related risks, discusses the applicability of the mode of enterprise financial shared service center from enterprise level and business level and proposes to the idea of establishing the mode of financial shared service center, hoping to help the improvement of financial management level of enterprises and development of enterprises.
\end{abstract} ideas

Keywords-Internet plus; financial sharing; construction

\section{INTRODUCTION}

With the advent of the Internet + era, the impact of new concept of era development such as new economic normal, industry 4.0, cloud computing and mobile Internet on the various fields and industries has become increasingly prominent. The traditional financial management mode can no longer meet the current need of financial informatization and large scale. In the 1980s, financial sharing was first applied to multinational management practices. As the global economic integration intensifies, more Fortune Global 500 companies began to practice and apply the mode of financial shared service center. According to statistics, $80 \%$ of the Fortune Global 500 enterprises have achieved financial sharing, such as Microsoft and IBM. Since 2005, many domestic enterprises in China have also started to implement centralized and effective financial sharing management, such as ZTE, Haier Group, Changhong Group, Vanke, Huawei, China Mobile, Guotai Junan Securities, China Telecom, China Netcom and TCL, and expected effect is obtained. Thus, the mode of financial shared service center is an innovative product of financial management in the Internet +

*Fund Project: 2017 School-level Financial Management Virtua Simulation Experiment Teaching Center (Project No. Z1704). era. However, on the whole, this mode is still in the growth stage in financial management mode of enterprises in China. Both theoretical research and practical experience need to be improved and there are still many deficiencies in the mechanism process, talent management and division of responsibilities of financial sharing center. How can we construct the mode of financial shared service center suitable for the development of enterprises in the Internet + era is an issue to be solved for the promotion and development of financial management mode of enterprise.

\section{RELATED THEORIES AND CONCEPTS OF FINANCIAL SHARED SERVICES}

The relative authoritative explanation of sharing services is Bryan Berger's definition in Essentials of Shared Services: "Sharing Services is a cooperative strategy that centralizes a portion of existing business function into a new semiautonomous business unit which has special regulatory agency like an enterprise that competes in the open market, aiming to increase efficiency, create value, save costs and provide quality service same to internal customers of parent company."

Financial Sharing Services, or FSS for short, refers that the enterprise group separates the dispersed and repeated financial accounting work from each business units and rebuilds a financial organization to conduct centralized and standardized management to financial work of the company relying on modern information technology and aiming at reducing operating and management costs, standardizing processes, improving efficiency and optimizing the organizational structure or creating value.

\section{THE NECESSITY FOR THE IMPLEMENTATION OF FINANCIAL SHARED SERVICE CENTER}

\section{A. To Reduce Operating Costs}

The practice and application of financial shared service center in the finance department of enterprise greatly reduced the operating costs of enterprises. First of all, financial shared service center centralized manages the financial personnel engaged in standardized work, which both 
enhances the management and control efforts and reduces the number of management levels and personnel; Second, the financial sharing service center centralizes the repeated accounting work and operational functions of all branches of enterprises to re-divide and define the relationship between financial and business. Streamlined operation and management of the daily financial work improve the efficiency of the financial staff in dealing with accounting documents and reduce the relevant cost of handling accounting documents in enterprises. According to statistics, the number of finance staff decreased from 32 to 15 after the implementation of financial shared services. The business scope change from the initial handling the business of enterprise group headquarters and branches to business of 44 corporate headquarters and organizations of the enterprise, the number of processing certificate per person has been raised from 335 to 716 , and the verification cycle of vouchers has also been shortened from thirty or forty days to less than five days. As a result, the financial operating efficiency and service quality have been correspondingly improved while reducing the financial operating costs.

\section{B. To Improve the Financial Operating Efficiency}

After the implementation of the financial shared service, the financial staff in each post is only engaged in one work through professional division of labor, and the business of all the constituent company adopts standardized operation procedures, which simplifies the unnecessary approval process and steps, effectively utilizes the scale advantage of accounting treatment and improves the work efficiency of the business processes. At the same time, with the advent of the Internet + era, the information system is fully utilized to speed up the transmission of business data and achieve financial data sharing, business accounting, cash collection and payment, and data aggregation and analysis. Crossregion and cross-department data sharing and integration is achieved, financial cost is reduced at the same time, standardization and update speed of information service system is promoted, and the efficiency of financial operations is improved.

\section{To Promote the Standardized Construction of Enterprises}

Before the implementation of financial shared services, the financial departments of all branches conducted accounting and supervision of various business types and processes for their respective accounting operations. Due to the differences in actual conditions such as resource allocation and business standards of places of each business, there is a certain degree of difficulty in data reduction. After the establishment of the financial shared service center, standardized management can be achieved through management system, business process and data size. It has implemented unified standard and norm to the routine accounting work of all business units, laying the foundation for standardized management in the enterprise field.

\section{To Strengthen the Financial Control Ability}

For group companies, through the establishment of financial sharing service center, each branch can complete the daily regular transaction business work in financial shared service center, and the finance department can shift the focus of work to financial functions such as financial analysis, financial decision-making and performance management. The financial department of the entire group company not only regulates the financial processes, norms and standards of the entire financial company, but also can strengthen the management of enterprises in investment, financing, tax planning, internal control and risk prevention and control. At the same time, a large number of finance staff can be devoted to their respective areas of financial management rather than to complicated routine work.

\section{THE RISKS RELATED TO BUILDING A FINANCIAL SHARED SERVICE CENTER}

\section{A. Separation of Finance and Management}

The establishment of financial shared service center promotes the standardization and process of the work pattern of financial staff. In addition, the centralized management of the business often results in the financial officers only accepting the business without knowing the actual production and operation situation of the enterprise or only knowing one aspect of the production and operation situation, lacking a comprehensive understanding of the financial status of the company. They can't make a reasonable, scientific basis for financial decisions if they are not familiar with the situation.

\section{B. High Construction Costs}

1) Costs of information system: The establishment of financial shared service center relies on a strong information system construction and information technology support. The expansion of business scale promotes the implementation of standardized financial management in financial work to establish financial shared service center. Under the traditional financial management methods, the contents of the financial management activities of the enterprises are all modularized, such as regular financial accounting, cash collection and payment, asset management and overall budget and son on. To integrate these businesses into the financial shared service center for unified accounting and management, we must resort to accelerating the development and establishment of information systems by enterprises.

2) Labor costs: The establishment of financial shared service center usually divides the work in accordance with the links of business process. The financial staff each link only need to grasp the work process standard that they are responsible for and mass and centralized operation mode are implemented in the financial sector, which apparently greatly reduces the phenomenon of redundant staff in accounting mechanism in the past. Thus, the clear job responsibilities, and scientific and rational division of labor 
significantly increase the work efficiency. However, when the mode of financial shared service mode was implemented initially, the original financial department needs to maintain operation in order not to affect the normal operation of the financial sector, and the new financial shared center also need to add new staff. The double allocation of personnel and the training cost of new finance staffs will increase the labor costs substantially.

\section{High Tax Risk}

China's tax administration is the principle of territoriality. Each enterprise is equipped with specialized financial staff tax for tax declaration to communicate with the local tax authorities, which can effectively reduce the sensitivity of tax risks of enterprises and strive for the convenience of various tax incentives. However, the establishment of financial shared service center and the implementation of standardization and process of financial work are difficult to achieve a comprehensive understanding of the financial status of enterprises and implement effective tax planning, so tax risks of enterprise have also been generated and increased.

\section{APPLICABILITY ANALYSIS OF MODEL OF FINANCIAL SHARED SERVICE CENTER}

Although the mode of financial shared service center plays an active role in reducing the operating costs of enterprises, improving the efficiency of financial operations, promoting the standardization of enterprises and strengthening the financial control ability of enterprises, this mode is not applicable to all financial management activities of enterprises. Enterprises should balance the benefits and costs of financial management activities after the implementation of mode of financial shared service center according to its own needs of business development and enterprise value, and select the financial management system and mode that is conducive to the development of the enterprise.

\section{A. Enterprise Level}

As a kind of innovative organization, the mode of financial shared service center is mainly suitable for two kinds of enterprises. First kind includes large-scale multinational enterprises and trans-regional enterprises. Due to the large scale and amount of business of the enterprises, the implementation of centralized management, unified accounting standards and business rules of financial shared center can effectively reduce the enterprise cost and improves the efficiency of financial operations and the standardization of enterprises. Second kind includes reorganized, merger and acquired enterprises, and enterprises with frequently changing organization structure. The centralized accounting treatment of financial shared service center reduces the requirements on the financial work caused by the changes in the organizational form of enterprises and promotes the standardization and process construction of the financial work of enterprises.

\section{B. Business Level}

Enterprises compare and analyze whether the business should be included in the scope of financial shared services based on correlation and complexity of business. It can confirm whether the business should be included in the financial shared service analysis mode by establishing a universal four-quadrant matrix of financial shared services, as shown below:

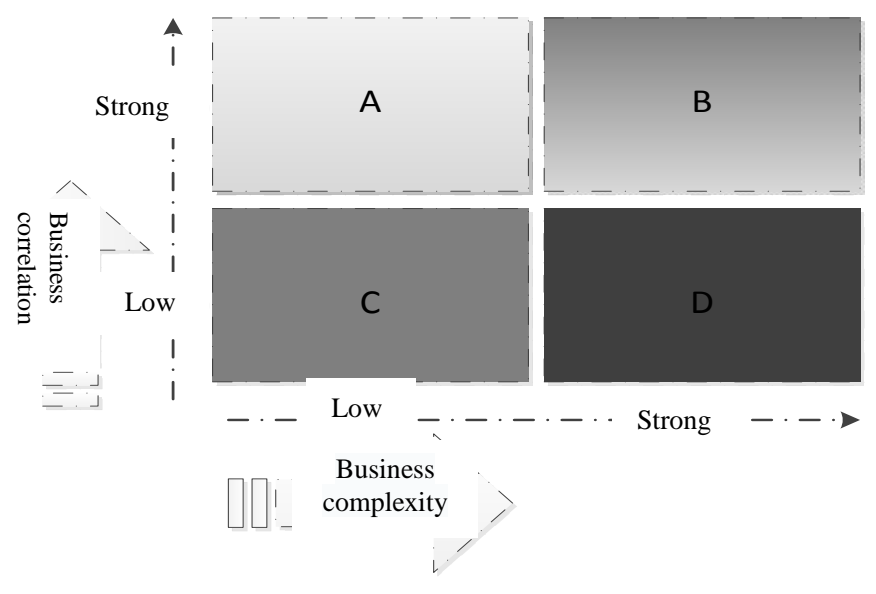

Fig. 1. Comparative analysis of correlation and complexity of business.

\section{Applicability Analysis}

- Area A: Enterprises located in Area A have low complexity and strong correlation of business. The decision-making ability of such business is not high, with strong repeatability, which is most suitable for standardized treatment made by the mode of financial shared service center. It can reduce costs and improve efficiency. For example, travel expenses reimbursement of various departments belongs to the business in this area.

- Area B: The business of enterprises in area B has high complexity and strong correlation. This type of business has a low probability of occurrence, but due to its strong correlation, it is suitable for standardized process management of the mode of financial shared service center. For instance, analysis of project feasibility needed by the enterprises due to expansion of the scale can be handed over to the financial shared center to provide professional consulting services.

- Area C: Enterprises in the area $\mathrm{C}$ have low business complexity and correlation. This type of business has low requirement on ability of judgment and decisionmaking ability. Enterprises can segment their businesses according to the size of correlation. The businesses with high correlation are suitable for using the mode of financial shared service center standardized process management and those with low correlation remains in the original business unit. In the case of multinational corporations dealing with 
specific matters concerning the host country where the business is located, different approaches should be formulated according to the environment of each region.

- Area D: The enterprises in the area D have high business complexity and low correlation. This type of business requires the professional judgment of professional managers. In addition, the weak correlation and the poor integration make each business department only set up relevant jobs or departments to carry out business process according to the needs, which is not suitable for using the financial shared service center.

\section{CONSTRUCTION IDEA OF MODE OF FINANCIAL SHARED SERVICE CENTER}

\section{A. The Control Point of Financial Management}

The financial management activities of the enterprise are the core components of the enterprise management activities. It plays a decisive role in prompting enterprises to continuously improve management and raising economic efficiency. After the enterprise implements the mode of financial shared service center, the control point of financial management mainly includes two aspects. First, under the premise of implementing a comprehensive budget, the financial management should also strengthen the monitoring of various fees and improve the efficiency of using funds. Second, we should strengthen the management and supervision over process of capital expenditures. Capital expenditures have the characteristic of large amount and long duration and so on. Therefore, after the promotion of the mode of financial shared service in enterprises, chief executive of the relevant business units and enterprise can supervise and control them timely so as to effectively avoid the financial risk.

\section{B. Financial Risk Prevention}

Under the mode of financial shared service management, the following problems arise in the financial management activities of the enterprise: firstly, segregation of duties is unclear; secondly, there is a lack of incentive mechanism; thirdly, standardization of processes of shared mechanisms is not achieved; fourth, there is a lack of assessment mechanisms. In response to the above problems, enterprises should make corresponding solutions. First, the financial shared center is divided into three centers: general ledger, expense and capital, so the division of duties should be clearly defined so as to avoid duplication of work among the three centers. The centers should communication with each other to ensure the smooth delivery of bills and funds and avoid the "vacuum zone" of business process; Second, after the enterprise establishes financial shared center, the work of financial officers become single and employees may lose their enthusiasm for career development. Therefore, enterprises should set up different appraisal mechanisms according to the positions of their employees, establish employees' awareness of post responsibility, and strengthen team management and communication and collaboration services between centers. Third, the management model of financial shared centers requires the standardization among enterprises and business processes and requires that image delivery mode be used in the document management, which saves financial human capital. Companies should look for key processes, analyze the expression of process, and optimize the process, to fully realize the standardized management of financial management sharing mechanism. Fourth, under the financial shared mode, content of financial work lacks comparability, so it is difficult to use the same evaluation criteria to assess. The companies use a "balanced scorecard" to make performance management from the four perspectives of financial, customer, internal operations, and learning and growth. Each center chooses the emphasis suitable for them to implement financial shared services.

\section{Improve the Financial System}

After the enterprise implements the management mode of financial shared service center, it should set up a set financial accounting system and process that suit the development needs of enterprises according to the latest requirements of the state financial management system so as to cover every department and every business of the enterprise to overcome the decentralized management of the traditional financial system and achieve the standardization, processing and scientificity of financial management. Thus, it can achieve that the financial work improve the efficiency with systematic management and standard services and provide good financial services practically for management level of the company.

\section{Analysis of Cost-effectiveness}

In the process of constructing the mode of financial shared service management, both the labor cost and the informationization cost are relatively high. According to the principle of cost-effectiveness analysis, it is inevitably present that the initial investment is large and the output is small and stable in the later period. Therefore, in the process of building the mode of financial sharing service, enterprises should handle the cost-effectiveness analysis, focusing on the comprehensive weigh from the aspects of human resources, technical support, and site selection of service center. It is not only necessary to meet the development requirement of standardization of financial management working process and informationization, but also cannot lead the business costs too high to lose the original intention of financial sharing service mode.

\section{CONCLUSION}

With the advent of the Internet + era, the financial management mode of financial shared services has been widely applied and promoted in many group enterprises and multinational corporations at home and abroad. The establishment of financial shared service center and the drive of economic globalization and the internationalization of enterprises help enterprises change the management concepts and financial management methods. This new financial management model is not only an opportunity but also a challenge for enterprise financial management, so enterprises 
need to comply with the development trend of the times to establish the financial management mode suitable for their own development needs and improve the level of financial management.

\section{REFERENCES}

[1] Yuan Linhua. Analysis on the Financial Services Shared Mode of Group Companies. Chinese \& Foreign Entrepreneurs, 2015 (36).

[2] Liu Tingyuan. Discussion on Financial Shared Service Management Mode of Enterprises. Research of Finance and Accounting, 2007 (02).

[3] Ministry of finance accounting. Interpretation of the job specification of Enterprise Accounting Informationization. 2014, (02).

[4] Li Yongnan, Zhou Junjie. An Empirical Study of the Key Factors in Implementing Financial Shared Services in Chinese Enterprise Groups. Accounting Research, 2013 (10).

[5] Zhang Shourui. Research on the Application of Financial Shared Service Center in Chinese Enterprises. Suzhou University, 2014.

[6] Chen $\mathrm{Hu}$, Chen Chunhua. Issues to be Concerned in the Implementation of Financial Shared Services. fiance \& accounting, 2011(08).

[7] Jiang Chenlei. Study on Dynamic Financial Management Mode under the Information Age. Productivity Research, 2014 (10). 